geographically (topography, rivers, roads) and economically an appendage of Pakistan. It is predominantly Muslim, and the Indian answer that religion is not to be the basis of the new Indian state, which contains many millions of Muslims, is not entirely conclusive for various reasons. On the other hand, it does appear that the Kashmiri, under Sheikh Abdullah, may prefer to avoid the rather strict Muslim state of Pakistan, with its somewhat feudal economic pattern, and join the new India. How the plebiscite would go if held at the present moment-or in a year, or five-is very much of a guess. How, likewise, a military struggle between Pakistan and India -and such a struggle would probably flame into a general war in the subcontinent, if not elsewhere-would go if the peaceful procedures of the United Nations were to fail, is also conjectural, except that it would be both prolonged and fanatical, given the character of the terrain and the attitudes of zealous patriots in both countries, in spite of Indian predominance in men and resources. It is obviously devoutly to be hoped that the United Nations Members can lead and aid India and Pakistan to a solution of the problem and do this without further dangerous delay.

Pitman B. Potrer

\title{
THE AMERICAN COMMITTEE ON DEPENDENT TERRITORIES
}

The presence in the American Continent of colonies and possessions of non-American Powers first became acute at the Meeting of Foreign Ministers at Habana in July, 1940. What if Germany, as appeared more than likely, should win the war and take over by way of conquest the colonies and possessions of the defeated Powers, Great Britain, France and Holland? The danger which had been foreseen at the Meeting of Foreign Ministers at Panama in 1939 had now become more imminent. It had always been a corollary of the Monroe Doctrine that the United States would oppose the transfer of colonies and possessions in America from one European Power to another, particularly if the latter was a strong Power capable of constituting a future danger to the United States. Under the circumstances, then, it was clear that the United States would be inflexibly opposed to the transfer of the colonies and possessions to Germany. A threat to the peace was presented, and under the terms of the Convention of $1936,{ }^{1}$ consultation was in order.

The Meeting of Foreign Ministers at Habana acted promptly. In spite of the danger involved in challenging Germany, the American States were unanimous in reaffirming in even more explicit terms the principle of collective security foreshadowed in the Convention of 1936 and in the

1 This Jouknat, Supp., Vol. 31 (1937), p. 53. 
Declaration of Lima of $1938 .^{2}$ Declaration XV of the Final Act at Habana proclaimed in the clearest terms that any attack by a non-American state against the integrity or inviolability of the territory, the sovereignty or the political independence of an American State should be considered "as an act of aggression against the States which sign this declaration." s The Meeting of Foreign Ministers then went on to adopt a convention based on the principle that any transfer of the sovereignty, jurisdiction or possession of American territory from one non-American Power to another as a result of the events which were then taking place in Europe would be regarded by the American Republics as against American principles and as a threat to their peace and security." Provision was made for the establishment of an Inter-American Commission for Territorial Administration, which was authorized to set up a provisional administrative régime to administer the territories in the interest of the security of America until such time as the territories were in a position to govern themselves or be restored to their former status.

Accompanying the convention was a declaration-resolution (No. XX) which made provision for emergency action pending the ratification of the convention. " The "Act of Habana," as it was called, recognized the danger to the peace and security of the American Republics of a transfer of possessions from one non-American country to another and created "an emergency committee" to apply the provisions of the Act and to assume administration of the region attacked or threatened. Provision was made that when the emergency ceased to exist the territories were to be organized as autonomous states or be restored to their previous status.

The situation was complicated by the fact that two of the American States had long-standing controversies with a non-American state, Great Britain, with respect to sovereignty over certain colonial possessions, Guatemala claiming sovereignty over Belize, otherwise known as British Honduras, and Argentina claiming sovereignty over the Falkland Islands. It was not merely a general principle, therefore, that was at issue, but a concrete interest on the part of the two American States. This interest would without doubt be promoted to the extent that the general principle might be successfully advanced. The defeat of Germany, therefore, did not close the matter. In 1947 Guatemala requested the Governing Board of the Pan American Union to include the topic of "European colonies in America" in the program of the Ninth International Conference of American States, to be held at Bogotá the following year. At the same time Guatemala submitted a draft declaration reciting in its preamble that the historical process of the emancipation of America would not be concluded "so long as there remain in the Continent regions subject to the status of colonies," and declaring:

2 Ibid., Vol. 34 (1940), p. 199.

4 Ibid., p. 28. s Ibia., Vol. 35 (1941), p. 15.

I Ibid., p. 18. 
That it is a just aspiration of the Republics of America that the status of colonies that subsists in the Continent be terminated.

Acting in accordance with the agenda prepared for it, the Bogotá Conference assigned the Guatemalan project to Committee VI dealing with Juridical-Political Matters. The Committee moderated the preamble of the project and at the same time extended its scope. As adopted by the Conference the resolution (XXXIII) ${ }^{\circ}$ was preceded by the strong statement "That it is a just aspiration of the American Republies that colonialism and the occupation of American territories by extra-continental countries should be brought to an end"; but the resolution itself went no further than to create an "American Committee on Dependent Territories," composed of one representative of each member of the Organization of American States, the purpose of which was "to centralize the study of the problem of the existence of dependent and occupied territories, in order to find an adequate solution to that question."

The Brazilian Delegation dissented, stating that, while under other circumstances the draft declaration might have merited its support, it considered that an inter-American conference was "not an appropriate forum for debating a question that affects the interests of countries outside the continent." A distinction was drawn between European possessions that were the subject of litigation and those that were not, the Brazilian Delegation pointing out that in the case of the former there were the accepted procedures of pacific settlement, while in the case of the latter there were the provisions of Article 73 of the Charter of the United Nations in accordance with which the Powers responsible for administering non-self-governing territories assumed a sacred trust to govern them, and that the attainment of self-government on the part of these territories must be brought about through the General Assembly of the United Nations. The Delegation of the United States likewise declined to sign the resolution, without, however, assigning reasons for its unwillingness to do so.

In accordance with the terms of the Bogotá Resolution the Committee was to be convoked by the Council of the Organization, by prior agreement with the Cuban Government, as soon as fourteen members had been appointed by their respective governments. The meeting was duly convoked for March 15, 1949, thirteen members being present, the Venezuelan member absenting himself because of a controversy between his government and the Government of Cuba. In anticipation of the meeting the Pan American Union prepared for the use of the members a volume of informative material giving the background and setting of the problem, accompanied by a select bibliography on dependent territories and other connected matters.

- Final Act of the Ninth International Conference of American States, Bogota, Colombia, March 30-May 2, 1948 (Washington, D. C., Pan American Union, 1948), p. 47. 
The plenary sessions of the Committee fell into two separate periods, the first lasting from March 15 to March 29, and the second lasting from July 11 to July 21, 1949. In the interval between the plenary sessions the Committee divided itself into subcommittees, dealing respectively with initiatives, credentials, regulations and budget, administration, colonies, and occupied territories. The main task of the Committee fell naturally to the last two of these subcommittees. Under the head of "colonies" or "colonial territories" the Committee enumerated the following list based upon the reports presented to the Secretary General of the United Nations in accordance with the provisions of Article $73(\mathrm{e})$ of the Charter relative to non-self-governing territories: Greenland, French Antilles, French Guiana, Clipperton Island, Dutch Antilles, Dutch Guiana or Surinam, Lesser British Antilles, Bahamas, Barbadoes, British Guiana, Jamaica and its dependencies, and Trinidad and Tobago. The designation "occupied territories" was used in the sense of territories held to be justly the property of American States but occupied de facto by a nonAmerican Power. These territories included Belize, or British Honduras, claimed by Guatemala, with a collateral interest on the part of Mexico, and the Malvinas or Falkland Islands, the South Georgia Islands, the South Sandwich Islands and Argentine Antarctic, claimed by Argentina.

First among the specific tasks assigned to the Committee on Dependent Territories by the Bogotá Conference was that of centralizing all information upon the problems referred to it by the Bogotá resolution. On the basis of this information the Committee was to study the situation presented with the object of seeking "pacific means of eliminating both colonialism and the occupation of American territories by extra-continental countries." Reports were to be submitted by the Committee to the governments dealing with the separate colonies, possessions and territories, and on the basis of these reports further action was to be taken by the first Meeting of Consultation of Ministers of Foreign Affairs to be held after presentation of the reports.

The Subcommittee on Colonies prepared a report, based upon a plan presented by the Cuban Delegation, setting forth for each separate colony geographical data, historic antecedents, population, culture, economic and social conditions, health and public assistance, and political conditions. These separate reports were based upon material furnished by the different delegations, together with information taken from a work published by the United Nations in 1948 bearing the title "Non-Autonomous Territories: Summary and Analysis of the Information Transmitted to the Secretary General in 1947," and from other sources believed by the subcommittee to be authoritative. While the reports upon the different colonies contain nothing that is original, they are on the whole reliable summaries of the items listed in the plan of work, and they show no bias 
or prepossession against the three European states to which the respective colonies belong.

Having prepared its studies upon the separate colonies there was little that the Subcommittee on Colonies could do by way of suggesting to the Committee practical measures to bring about the desired objective. The colonial system could be condemned in as strong language as the Committee might choose to adopt, but beyond that the Committee could only appeal to the three non-American Powers to coöperate, in the hope that they might be influenced by the public opinion of the countries participating in the Committee. The resolution adopted by the Committee bears the lengthy title: "Request for the Coöperation of Non-American Countries to the End that their American Colonies and Possessions may be Established as Independent States or Placed under the Trusteeship System of Administration in Conformity with the Charter of the United Nations." ? The preamble of the resolution proclaims that "the colonial system is manifestly undergoing a process of liquidation" which dates from the end of the first world war, that the American Hemisphere cannot remain aloof from the process, and that as long as colonies exist in the Western Hemisphere America will not have achieved its complete political integration. The resolution itself requests the non-American countries having possessions in America to coöperate in solving the problem, "to the end that their colonies and possessions may be established as independent and democratic states." It recognizes, however, that certain colonies may not be prepared as yet to enjoy independence, in which case steps should be taken to have the colony placed under the trusteeship system of the United Nations. Lest colonies be confused with occupied territories, an exception is entered in respect to the latter, which were to be made the subject of a special recommendation.

Whether there would be any practical gain for the American States in having the more advanced British, French and Dutch colonies "established as independent and democratic states" was not seriously considered, so far as the records indicate. Nor was serious consideration given to the fact that the more backward colonies might continue in much the same condition if they were to be converted into trust territories with the same mother countries acting as administering authorities. What the Committee sought to do was to proclaim a principle, and thus gain indirect support for the position it was to take in the matter of occupied territories.

In marked contrast with the report of the Subcommittee on Colonies was the report prepared by the Subcommittee on Occupied Territories, which was of a distinctly polemical nature, being a justification on the part of Guatemala and Argentina of their claims to sovereignty over the

7 Resolution V, Acta Final de la Comisión Americana de Territorios Dependientes, Habana, July 21, 1949 (Pan American Union, Cong. and Conf. Series, No. 57), p. 9. 
areas occupied de facto by Great Britain. The very fact that Belize and the Malvinas and Antarctic Islands were designated as "occupied territories" was sufficient to indicate that the case with regard to these territories was a closed one. The reports, therefore, omit the informative material presented by the Subcommittee on Colonies and confine themselves to communications and declarations received from Guatemala and Argentina.

The case of Belize was complicated by the fact that Guatemala's claim against Great Britain was in turn contested by Mexico as to that part of Belize bordering on Yucatan; and the report of the subcommittee contains two communications from the Government of Mexico submitted in justifcation of the claim. Inasmuch, however, as Resolution XXXIII of the Bogotá Conference had been limited to seeking pacific methods for the elimination of the occupation of American territories by extra-continental countries were referred to a Meeting of Consultation of Foreign Ministers, ment upon the Mexican claim. Instead it submitted a draft agreement which appears in the Final Act under the title: "III. Reports and Communications on Belize," 8 in which the documents presented by the two countries were referred to a Meeting of Consultation of Foreign Ministers, or it might be to the next Inter-American Conference, accompanied by a wish that the differences between the two countries should be solved by the pacific procedures set forth in American treaties in force.

When the subcommittee came to propose a recommendation upon the controversy between Guatemala and Great Britain, it found itself embarrassed by the unwillingness of Guatemala to accept the Mexican claim on the same basis as its own. In consequence the draft of a recommendation submitted by the Working Group, which called upon Great Britain to submit the controversy with Guatemala to a decision ex aequo et bono of the International Court of Justice, and which contemplated that Mexico might be permitted to intervene in the case in accordance with the terms of Article 62 of the Statute of the Court, was opposed by Guatemala on the second point. The recommendation was then divided into two parts, the first part being adopted and the second part being defeated for lack of the necessary two-thirds majority. The Mexican Delegation thereupon withdrew from the Committee. A compromise was, however, later worked out, in accordance with which the "agreement" entitled "Reports and Communications on Belize" was submitted to the Committee, accompanied by a resolution entitled: "IV. Solidarity with the Just and Legitimate Claims of the American Nations in Relation to the Occupied Territories." ? The resolution, while repeating in its preamble the strong language of the preamble of Resolution XXXIII of the Bogotá Conference in respect to the elimination from the Continent of every status of dependency, what-

8 Op. oit., p. 8.

- Ibid. 
ever its form, political, economic or juridical, goes no further than "To express its sympathy with every just and legitimate claim of any American nation, to reaffirm the principles relative to the emancipation of America that have been solemnly set forth in the International Conferences of American States, and to adopt as its rule of conduct the pacific settlement of all disputes in accordance with justice and international law."

It was to be expected that certain elements in Puerto Rico which are not satisfied with the large measure of self-government which the island enjoys, but seek its complete independence should take advantage of the meeting of the Committee on Dependent Territories to advance their cause. The Independence Party and the Nationalist Party both presented numerous communications; and while the Committee was unwilling to admit representatives of the two organizations as observers, it allowed them the privilege of submitting reports to the Committee in writing.

On March 28, 1949, at its seventh plenary session, the Committee decided that it was competent to take cognizance of the case of Puerto Rico; but in view of doubts expressed by a number of the delegates, it was decided that, without interrupting consideration of the problem, the question of competence should be referred to the Council of the Organization of American States. The Council, on its part, considered the matter at its session of April 21, and referred it to its Committee on Inter-American Organizations. At a later meeting on May 26, after receiving the report of its Committee, the Council decided that, in view of the fact that the Charter of the Organization contained no specific provisions in respect to bodies such as the Committee on Dependent Territories, and the governments alone were competent to decide upon the meaning of the resolutions adopted at conferences, the decision of the Committee on the matter of competence which had been referred by the Committee to the Council should be in turn referred to the governments through their respective representatives on the Council, inquiring of them

- whether Resolution XXXIII of Bogotá authorized the said Commission to study the situation of any American territory which finds itself under the sovereignty and effective jurisdiction of any American State.

In the meantime, offsetting the reports presented to the Committee by the two political parties, the Senate of Puerto Rico adopted, on April 15, 1949, a unanimous resolution censuring the action of the Committee and stating that Puerto Rico would make its own decision on the matter of its future relationship to the United States. Puerto Rico, the resolution stated, enjoyed all the rights of American citizens, and it would be granted independence immediately if it were asked for. Paralleling the action of the Senate of Puerto Rico was a cable from the Puerto Rican Association of Women for Statehood, which expressed the desire of the Association "to 
inform this Committee that the last general elections show by an overwhelming majority that Puerto Rico does not desire to detach itself from the United States of America, of which it is not in fact a colony but a potential state."

On the date of the signing by the Committee of its Final Act thirteen governments had replied to the inquiry submitted by the Council of the Organization, three pronouncing in favor of the competence of the Committee to study the case of Puerto Rico and ten opposing, with eight governments failing to answer. In this situation the Committee adopted unanimously a resolution entitled: "VI. Study of the Case of Puerto Rico," 10 which, after reciting the circumstances of the case of Puerto Rico, transmits to the Council of the Organization all of the antecedents and reports with reference to Puerto Rico "in order that the Council may deal with them as it considers proper"; and it declares :

that, in view of the present economic, political, and social situation in Puerto Rico, the Committee hopes that this nation will have an opportunity to express itself definitely and freely so as to decide its own destiny.

The Final Act was signed on July 21 and the meeting came to an end. In accordance with the resolution of the Bogotá Conference the Committee submitted its report to the individual American governments "for their information and study," and the report became thereupon an item on the agenda of the next Meeting of Consultation of Ministers of Foreign Affairs. ${ }^{11}$

C. G. FenwrCK

\section{UNITED STATES TREATY DEVELOPMENTS}

In July, 1948, the Department of State inaugurated a loose-leaf service entitled United States Treaty Developments. ${ }^{1}$ The compilation is designed to meet the long-felt needs of the Department and of international lawyers, historians and research workers for a continuously up-to-date reference service providing factual information on developments affecting international agreements entered into by the United States. The project, which was urged upon the Department of State by a committee of the American Society of International Law under the able guidance of Professor Willard B. Cowles, ${ }^{2}$ is being compiled under the direction of Mr. Bryton Barron of the Office of the Legal Adviser, Department of State.

10 Op. cit. (note 7, supra), p. 10.

11 Informe de la Comisión Americana de Territorios Dependientes, La Habana, 1949; Memoria de la Comisión Americana de Territorios Dependientes, La Habana, 1949.

1 United States Treaty Developments. Department of State Publication 2851. Washington: U. S. Government Printing Office. 1st Release (dated August, 1947), July, 1948, \$4.00; 2nd Release (dated June, 1948), April, 1949, \$3.25; 3rd Release (dated December, 1948), October, 1949, $\$ 3.50$; 4th Release (dated June, 1949) (in proof).

2 See Proceedings, American Society of International Law, 1946, pp. 184-190;id., 1947, pp. 172, 203 ; id., 1948, pp. 119, 162. 